\title{
Measurement of Mercury in Flue Gas Based on an Aluminum Matrix Sorbent
}

\author{
Juan Wang, Wei Xu, Xiaohao Wang, and Wenhua Wang \\ School of Environmental Science \& Engineering, Shanghai Jiao Tong University, 800 Dongchuan Road, \\ Shanghai 200240, China
}

Received 24 June 2011; Accepted 13 October 2011

Academic Editor: Richard Brown

The measurement of total mercury in flue gas based on an economical aluminum matrix sorbent was developed in this paper. A sorbent trap consisted of three tubes was employed to capture $\mathrm{Hg}$ from flue gas. Hg trapped on sorbent was transferred into solution by acid leaching and then detected by CVAAS. Hg adsorbed on sorbent was recovered completely by leaching process. The $87.7 \%$ recovery of $\mathrm{Hg}$ in flue gas by tube 1 and tube 2 was obtained on the equipment of coal combustion and sampling in lab. In order to evaluate the ability to recover and accurately quantify $\mathrm{Hg}^{0}$ on the sorbent media, the analytical bias test on tube 3 spiked with $\mathrm{Hg}^{0}$ was also performed and got the average recovery of $97.1 \%$. Mercury measurements based on this method were conducted for three coal-fired power plants in China. The mercury in coal is distributed into bottom ash, electrostatic precipitator (ESP) ash, wet flue gas desulfurization (WFGD) reactant, and flue gas, and the relative distribution varied depending on factors such as the coal type and the operation conditions of plants. The mercury mass balances of three plants were also calculated which were $91.6 \%, 77.1 \%$, and $118 \%$, respectively. The reliability of this method was verified by the Ontario Hydro $(\mathrm{OH})$ method either in lab or in field.

KEYWORDS: Mercury, flue gas, measurement method, sorbent trap, mass balance 


\section{INTRODUCTION}

Mercury is considered as a true global pollutant due to its toxicity, volatility, persistence, and long-range transport in the atmosphere. Global Hg emissions were reviewed for the year 2000 in detail by Pacyna et al. [1]. And it was observed that two thirds $(1.46 \mathrm{kt})$ of the total atmospheric emission $(2.19 \mathrm{kt})$ originate from coal combustion. Increasing awareness of the mercury emissions from coal-fired flue gas has led to many efforts to develop strategies and technologies to control $\mathrm{Hg}$ emission. $\mathrm{Hg}$ measurement in flue gas in a more convenient way has been paid more attention to.

At present, many methods for sampling and quantifying $\mathrm{Hg}$ in flue gas are used. Several standard EPA sampling procedures $(29,101 \mathrm{~A}$, and $\mathrm{OH}$ methods) have been widely recommended for the determination of particulate and gaseous mercury emissions from stationary sources [2-4]. These EPA methods are based on isokinetic sampling of the flue gases at a suitable sampling point using a filter collection system for particulates firstly. The sampled gases then pass through a set configuration of impingers containing liquid absorbents such as $\mathrm{KCl}, \mathrm{HNO}_{3} / \mathrm{H}_{2} \mathrm{O}_{2}$, and $\mathrm{KMnO}_{4} / \mathrm{H}_{2} \mathrm{SO}_{4}$ to trap any mercury present in the sample gases. Some other aqueous oxidative solutions were tested by Shendikar et al. [5], such as $10 \% \mathrm{H}_{2} \mathrm{O}_{2}$, acidified $10 \% \mathrm{H}_{2} \mathrm{O}_{2}, 0.2 \mathrm{M}\left(\mathrm{NH}_{4}\right)_{2} \mathrm{~S}_{2} \mathrm{O}_{8}, 0.2 \mathrm{M}\left(\mathrm{NH}_{4}\right)_{2} \mathrm{~S}_{2} \mathrm{O}_{8}+0.025 \mathrm{M} \mathrm{AgNO}_{3}$, and $1.5 \% \mathrm{KMnO}_{4}$ in $10 \% \mathrm{H}_{2} \mathrm{SO}_{4}$. Good collection efficiencies for $\mathrm{Hg}^{0}$ by using more than one impinger were exclusively obtained by the last two mixed solutions. $\mathrm{K}_{2} \mathrm{Cr}_{2} \mathrm{O}_{7}(4 \%)$ in $4 \mathrm{M} \mathrm{HNO}_{3}$ solution was used to sample $\mathrm{Hg}$ in flue gas of a coal-fired power plant by Meij [6].

Furthermore, many solid mediums were used for the collection of $\mathrm{Hg}$ from flue gas. In Frontier Geosciences Mercury Speciation Method [7], flue gas passes through a set of two KC1/soda lime traps and two iodated carbon traps. $\mathrm{Hg}^{2+}$ and $\mathrm{Hg}^{0}$ are collected by the two different sorbents, respectively. In MIT's Solid Sorbent Method [8], flue gas passes through two activated charcoal sorbent traps connected in series. The traps capture $\mathrm{Hg}^{2+}$ as well as $\mathrm{Hg}^{0}$. In HEST Method [9], carbon-impregnated filters are used to adsorb gas phase $\mathrm{Hg}$. And activated carbon treated with iodine or some other halogen has been applied to capture total $\mathrm{Hg}$ in flue gas in EPA method 30B [10] and method Appendix K [11].

These methods could be classified in two main groups: methods to employ impingers with oxidant solutions and methods based on solid sorbents. Although the latter is easier to handle than the former, it was found in most of the solid sorbents that the collection efficiency of $\mathrm{Hg}^{0}$ was decreased with the increasing temperature of flue gas and the increasing level of $\mathrm{SO}_{2}$ [12-14]. Thus, a number of disadvantages in the methods based on solid sorbents have to be improved.

In the previous work $[15,16]$ in our lab, a series of aluminum-matrix-based sorbents were prepared to convert $\mathrm{Hg}^{0}$ to $\mathrm{Hg}^{2+}$ by catalytic oxidation and then absorb it. Some characteristics of the sorbents such as the size of the particles, crystal structures, binding energies, Brunauer-Emmett-Teller- (BET-) specific surface area $\left(\mathrm{S}_{\mathrm{BET}}\right)$, and pore size distribution were analyzed, respectively. The catalytic and adsorption tests were carried out with a flow of simulated flue gas (consisted of $\mathrm{N}_{2}, \mathrm{O}_{2}, \mathrm{SO}_{2}, \mathrm{NO}$, and $\mathrm{HCl}$ ). These sorbents have shown a good $\mathrm{SO}_{2}$ antipoisoning ability and a stable oxidation and adsorption abilities during the change of temperatures. Furthermore, they can be regenerated by thermal decomposition above $500^{\circ} \mathrm{C}$ easily. This feature made the application of these sorbents more economical than carbon-based sorbents, especially in China.

Based on these materials, the sorbent AL- $\mathrm{CCl}\left(\mathrm{CuCoO}_{4}+\mathrm{NH}_{4} \mathrm{Cl}\right.$ loaded on $\left.\gamma-\mathrm{Al}_{2} \mathrm{O}_{3}\right)$ was selected as the collection medium to capture $\mathrm{Hg}$ in flue gas. Sampling and detection approach was established with small system for coal combustion and flue gas sampling in this work in lab and was applied in three power plants in China. The overall mass balances have been calculated to evaluate the efficiency of this method and the reliability has been verified with $\mathrm{OH}$ method.

\section{EXPERIMENT}

\subsection{Materials and Determine Method}

$\mathrm{CuCoO}_{4}+\mathrm{NH}_{4} \mathrm{Cl}$ loaded on $\gamma-\mathrm{Al}_{2} \mathrm{O}_{3}(\mathrm{AL}-\mathrm{CCl})$ was prepared by impregnating $\mathrm{AL}-\mathrm{C}\left(\mathrm{CuCoO}_{4}\right.$ loaded on $\gamma-\mathrm{Al}_{2} \mathrm{O}_{3}$ ) with $30 \mathrm{wt} \% \mathrm{NH}_{4} \mathrm{Cl}$ solutions before the decomposition, dried at $60^{\circ} \mathrm{C}$, and then calcined 
TABLE 1: Major components of BCR-40 and coal sample (dry air basis).

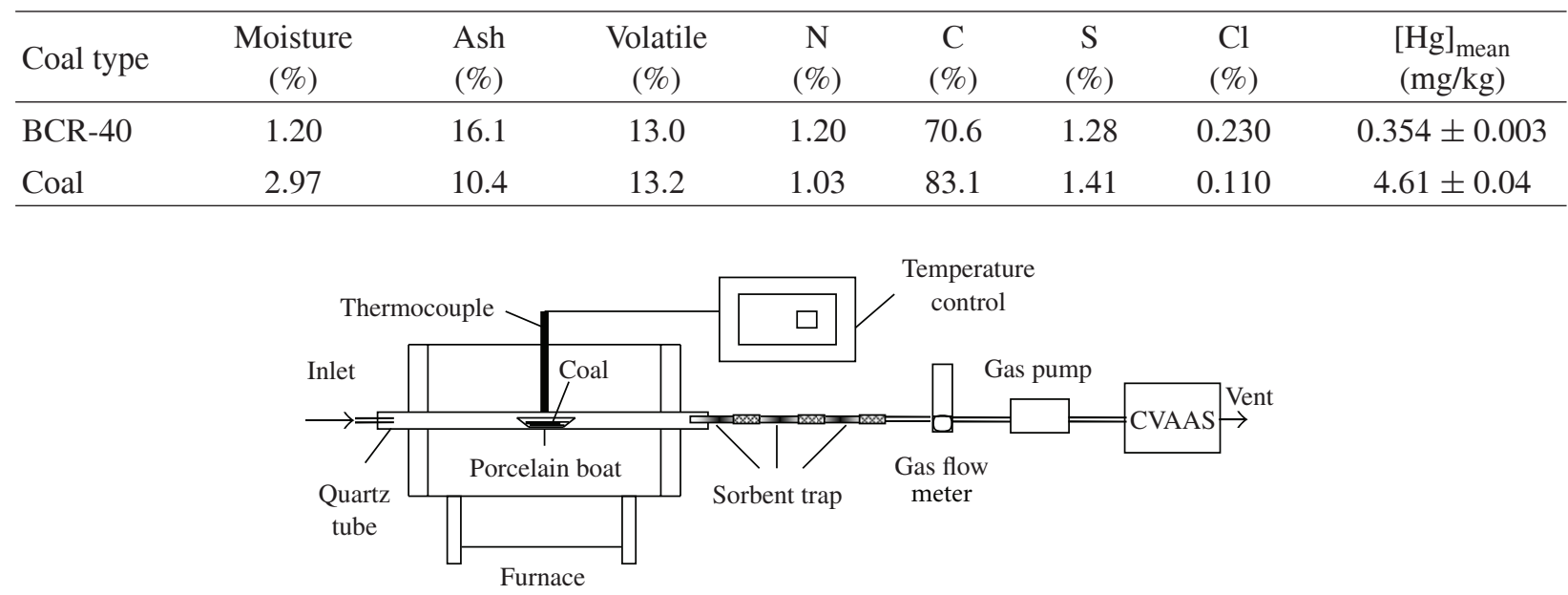

FIGURE 1: Schematic diagram of the coal combustion and sampling system.

at $400^{\circ} \mathrm{C}$ for $3 \mathrm{~h}$. AL-C was prepared by the thermal decomposition of $\mathrm{Cu}$-nitrate/Co-nitrate mixtures loaded on $\gamma-\mathrm{Al}_{2} \mathrm{O}_{3}$. Both nitrates were mixed in $\mathrm{Co} / \mathrm{Cu}$ atomic ratio of 1 . The mixtures were dissolved in water to form the mixtures solution. $\gamma-\mathrm{Al}_{2} \mathrm{O}_{3}$ was impregnated by the mixtures solution in proportion to $20 \mathrm{wt} \%$ nitrate loading values and heated to $230^{\circ} \mathrm{C}$, the temperature at which nitrogen oxides were evolved. The heterogeneous mass obtained was ground in a mortar and heated for $5 \mathrm{~h}$ at $400^{\circ} \mathrm{C}$.

Coal sample from the south-west China was used in lab research after the pretreatment of grinding and sieving. They were digested in $\mathrm{V}_{2} \mathrm{O}_{5}-\mathrm{HNO}_{3}-\mathrm{H}_{2} \mathrm{SO}_{4}$ solution firstly and then the digestate solution was determined by a cold vapor atomic adsorption spectrometry mercury analyzer (CVAAS, SG-921, Jiangfen Ltd.). A standard reference material (BCR-40) with a certified value for mercury $(0.35 \pm 0.06 \mathrm{mg} / \mathrm{kg})$ was introduced for quality control. All chemicals were of analytical grades. The major components of BCR-40 and coal are listed in Table 1.

The mercury concentration of BCR-40 was detected in an average value of $0.354 \pm 0.003 \mathrm{mg} / \mathrm{kg}$ $(n=5)$ with the relative error $<2 \%$ compared to certified value. Therefore, the determination course was reliable.

\subsection{Sample Collection}

Mercury in flue gas was collected using a sorbent trap with three tubes connected by Teflon sleeves. All the tubes were made by the quartz tube $(50 \mathrm{~mm}$ in length with an outer diameter of $10 \mathrm{~mm}$ and an inner diameter of $7.5 \mathrm{~mm}$ ) containing approximately $1 \mathrm{~g}$ sorbent which was sandwiched and fixed by the quartz cotton. Among them, the tube 1 was designated for primary capture of gaseous $\mathrm{Hg}$. The tube 2 was designated as a backup to check vapor phase $\mathrm{Hg}^{0}$ breakthrough. For the third tube, a known mass of $\mathrm{Hg}^{0}$ was spiked to perform the analytical bias test and spiked $\mathrm{Hg}^{0}$ recovery study. Each sorbent trap was marked with an identified number for tracking.

In lab research, mercury collection experiment was carried out on the equipment of coal combustion and sampling shown in Figure 1. A porcelain boat with the coal was put into a quartz tube $(650 \mathrm{~mm}$ in length with an outer diameter of $36 \mathrm{~mm}$ and an inner diameter of $32 \mathrm{~mm}$ ), which crossed through a clamshell furnace. Figure 2 presents that $\mathrm{Hg}$ emission was started from $150^{\circ} \mathrm{C}$ in furnace and the maximum emission was got during $240-250^{\circ} \mathrm{C}$. In Figure 3, it can be seen that most all of volatile mercury in coal was released into flue gas at $600^{\circ} \mathrm{C}$. Therefore, the temperature in furnace was maintained at $600^{\circ} \mathrm{C}$. The gas pump was turned on before trapping $\mathrm{Hg}$ and adjusted the gas flow meter at an appropriate flow rate $(0.3-0.5 \mathrm{~L} / \mathrm{min})$. Then, coal-fired flue gases were extracted through the sorbent trap. Sampling time was 


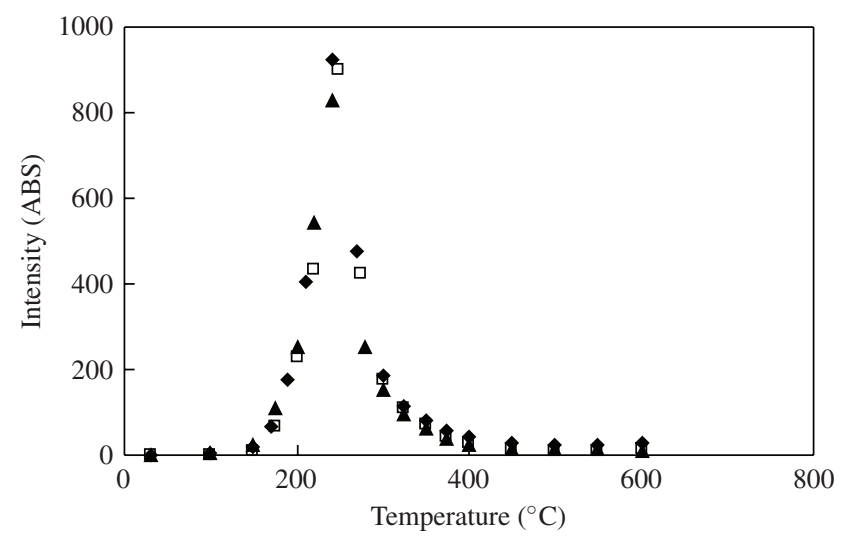

- Sample 1

口 Sample 2

A Sample 3

FIGURE 2: Hg emission from coal with the increased temperature in furnace.

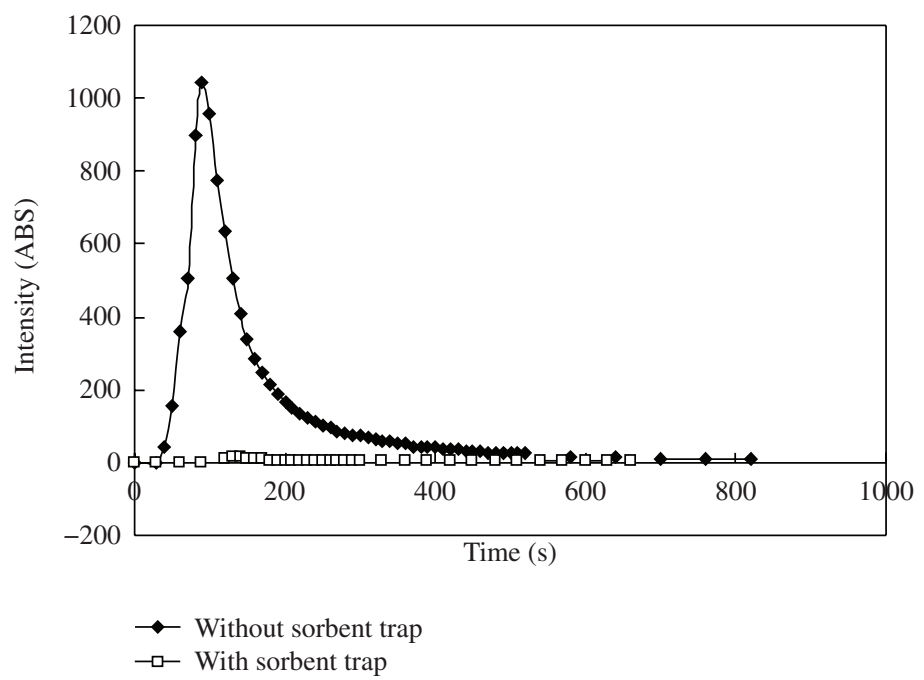

FIGURE 3: Hg emission from coal with and without sorbent trap at $600^{\circ} \mathrm{C}$.

remained for 5 minutes. The CVAAS at the end of the equipment in Figure 1 was connected in order to monitor any mercury in gas path. After trapping, the mercury content in coal ash was tested with the same procedure of coal, and the average mercury concentration $(1.50 \pm 0.11 \mathrm{mg} / \mathrm{kg}, n=15)$ was obtained.

Field mercury emission measurements based on this method were practiced in three coal-fired power plants in China. Table 2 and Figure 4 present the detailed configurations and sampling sites during the course of flue gas in the three power plants tested in this study.

As shown in Figure 5, the test gases were sampled from the flue gas stream at an appropriate flow rate $(0.3-0.5 \mathrm{~L} / \mathrm{min})$ through a heated probe which prevented the condensation to occur before the gas entered the sorbent trap(s). A water knockout after the sorbent trap was placed to prevent the water in sample line from entering the flue gas sampler (TH-600, Tianhong, China). The samples were simultaneously taken from both the inlet and outlet of the pollutants control devices, for example, ESP and WFGD, as shown in Figure 2. According to the results of pretest, 2 hours were enough for the gas phase mercury detection. After the sampling, each tube of the sorbent trap was immediately placed into Hg-free containers for subsequent laboratory detection. The characteristics (such as gas temperature, static pressure, and gas velocity) and 
TABLE 2: Power plant configurations.

\begin{tabular}{lllcc}
\hline $\begin{array}{l}\text { Power } \\
\text { plant no. }\end{array}$ & Boiler type & Coal type & $\begin{array}{c}\text { Capacity } \\
(\mathrm{Mw})\end{array}$ & $\begin{array}{c}\text { Pollution control } \\
\text { device }\end{array}$ \\
\hline 1 & Pulverized coal & bituminous coal & 98 & ESP + WFGD \\
2 & Supercritical & bituminous coal & 758 & ESP + WFGD \\
3 & Pulverized coal & bituminous coal & 100 & ESP + WFGD \\
\hline
\end{tabular}

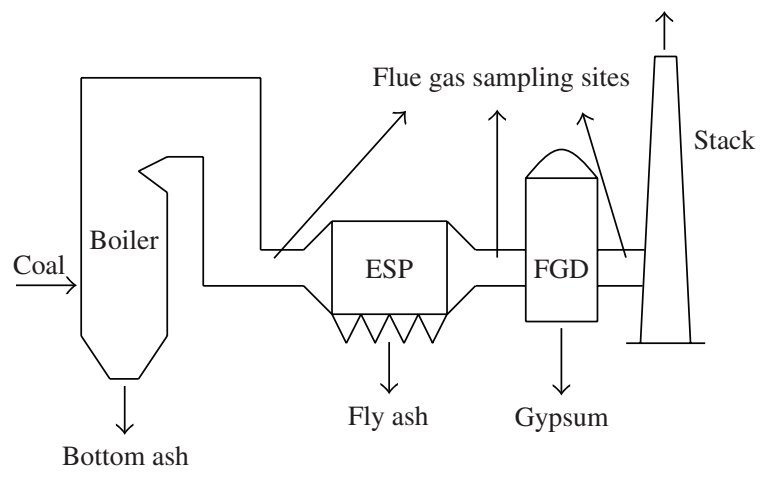

FIGURE 4: Simultaneous power plant sampling locations.

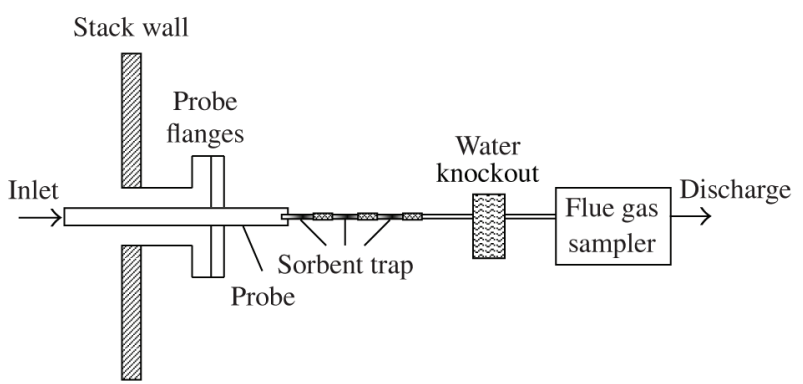

FIGURE 5: Sampling train in field.

main components (such as $\mathrm{SO}_{2}, \mathrm{NO}_{x}$, and $\mathrm{O}_{2}$ ) of the flue gas were determined by the flue gas analyzer (350$\mathrm{XL}$, Testo, German) during the sampling period. Solid samples, including the pulverized coal, bottom ash, fly ash captured in ESP, and gypsum in the WFGD, were taken after half-hour Hg trapping. The sampling was conducted two or three times for each power plant to obtain the parallel results and reduce uncertainties. The data obtained from tests at the same conditions were averaged to get the final results.

\subsection{Detection of $\mathrm{Hg}$ in Flue Gases}

The individual tube of the the sorbent trap and their respective components were detected separately. Sorbent media, quartz cotton, and fly ash deposited on the quartz cotton in each tube were moved into a glass funnel, which was covered with a piece of filter paper. Then, they were eluted by $50 \mathrm{~mL} 4 \mathrm{~mol} / \mathrm{L} \mathrm{HCl}$-saturated $\mathrm{KCl}$ solution and the captured mercury was transferred into liquid solution. The mercury concentrations were measured on the CVAAS (SG-921, Jiangfen, China). The amount of $\mathrm{Hg}$ contents in tube 1 and tube 2 reflected the total mercury concentration in the flue gas. From the results detected in tube 3 spiked with known mass of $\mathrm{Hg}^{0}$, the recovery and performance of the combined sampling and analytical approach could be verified. The solid samples taken from the power plants were measured by a Zeeman Mercury Spectrometer (RA- $915^{+}$, Lumex, Russia). All the instruments were calibrated before the samples analyses. 
TABLE 3: Recovery of spiked $\mathrm{Hg}^{0}$ in tube 3 in lab test $(n=3)$.

\begin{tabular}{lcccc}
\hline $\begin{array}{l}\text { Coal consumption } \\
(\mathrm{g})\end{array}$ & $\begin{array}{c}\mathrm{Hg} \text { emission } \\
\text { from coal }(\mu \mathrm{g})\end{array}$ & $\begin{array}{c}\mathrm{Hg}^{0} \text { spiked in } \\
\text { tube } 3(\mu \mathrm{g})\end{array}$ & $\begin{array}{c}\mathrm{Hg}^{0} \text { recovered } \\
\text { from tube } 3 \\
(\mu \mathrm{g})\end{array}$ & $\begin{array}{c}\text { Average } \\
\text { recovery }(\%)\end{array}$ \\
\hline 0 & 0 & 0.25 & $0.243 \pm 0.002$ & 97.3 \\
1.0 & 3.11 & 0.25 & $0.247 \pm 0.012$ & 98.7 \\
2.0 & 6.22 & 0.25 & $0.241 \pm 0.020$ & 96.2 \\
3.0 & 9.33 & 0.25 & $0.224 \pm 0.003$ & 89.7 \\
4.0 & 12.44 & 0.25 & $0.263 \pm 0.041$ & 105 \\
5.0 & 15.55 & 0.25 & $0.238 \pm 0.036$ & 95.4 \\
\hline
\end{tabular}

Hg emission from coal $(\mu \mathrm{g})=(4.61-1.50)(\mu \mathrm{g} / \mathrm{g}) \times$ coal consumption $(\mathrm{g})$. Average recovery $(\%)=\left[\mathrm{Hg}^{0}\right.$ recovered from tube $\left.3(\mu \mathrm{g}) \div 0.25(\mu \mathrm{g})\right]$ $\times 100 \%$.

\section{RESULTS AND DISCUSSION}

\subsection{Recovery of $\mathrm{Hg}$ Analysis in Lab}

\subsubsection{Recovery of Spiked $\mathrm{Hg}^{0}$ in Tube 3 of the Sorbent Traps}

The ability to recover and accurately quantify $\mathrm{Hg}^{0}$ on the sorbent media was evaluated by performing the analytical bias test on the tube 3 spiked with $\mathrm{Hg}^{0}$. Mercury concentrations in the tube 3 were analyzed using the same procedure above. In Table 3, the average $\mathrm{Hg}^{0}$ recovery of $97.3 \%$ in tube 3 was got without coal combustion. The specific verification of the performance of the combined sampling and detection approach was also provided by performing the spiked $\mathrm{Hg}^{0}$ recovery test. As shown in Table 3, the average $\mathrm{Hg}^{0}$ recovery of tube 3 varied from $89.7 \%$ to $105 \%$ (averaged $97.0 \%$ ) with increasing of coal consumption. It is demonstrated from the aforementioned results that the sorbent media in tube 1 and tube 2 possessed efficient capacity of mercury adsorption and there was no vapor phase $\mathrm{Hg}$ breakthrough. Also spiked $\mathrm{Hg}^{0}$ in tube 3 was not affected by the flue gas passed by. Therefore the approach of sampling and detection in this study was validated in summary.

\subsubsection{Recovery of $\mathrm{Hg}$ in Flue Gas}

Hg recovery in tube 1 and tube 2 of the traps after sampling was calculated to evaluate the feasibility and accuracy of this method. In Table 4, the Hg content in original sorbent media before sampling was under the lowest test limitation, which indicated that $\mathrm{Hg}$ was thoroughly removed from the sorbent during the baking procedure. And as the increasing of coal consumption, $\mathrm{Hg}$ content in tube 1 increased simultaneously with a good value of the square of the linear correlation coefficient (i.e., $R^{2}=0.998$ ) as shown in Figure 6 . However, $\mathrm{Hg}$ content in tube 2 presented irregular and negligible compared to that of tube 1 . The average recovery of tube 1 and tube 2 varied from $83.0 \%$ to $94.3 \%$ (averaged 87.7\%). Due to the complex composition of flue gas, the adsorption of $\mathrm{Hg}$ by the sorbent was affected by many uncertain factors, such as fluctuations in coal, ash, flue gas flow rates, sampling uncertainty, and measurement uncertainty. Yokoyama et al. [17] considered that the results between 70 and $130 \%$ are acceptable due to the difficulties in estimating each uncertainty.

\subsubsection{Reliability Verification of Flue Gas Measurements with OH Method in Lab}

In order to verify the reliability of flue gas measurements performed by the new sorbent, the approved method, $\mathrm{OH}$ method has been used simultaneously in lab. As shown in Table 5, the $\mathrm{Hg}$ measurement results of this method were closed to those of $\mathrm{OH}$ method. The relative errors of the results between two methods 
TABLE 4: Recovery between $\mathrm{Hg}$ trapped in flue gas and $\mathrm{Hg}$ emission from coal $(n=3)$.

\begin{tabular}{lcccc}
\hline $\begin{array}{l}\text { Coal consumption } \\
(\mathrm{g})\end{array}$ & $\begin{array}{c}\text { Hg emission } \\
\text { from coal }(\mu \mathrm{g})\end{array}$ & $\begin{array}{c}\text { Hg trapped in } \\
\text { tube } 1(\mu \mathrm{g})\end{array}$ & $\begin{array}{c}\text { Hg trapped in } \\
\text { tube 2 }(\mu \mathrm{g})\end{array}$ & $\begin{array}{c}\text { Average } \\
\text { recovery }(\%)\end{array}$ \\
\hline 0 & 0 & Not detected & Not detected & Not detected \\
1.0 & 3.11 & $2.92 \pm 0.03$ & $0.017 \pm 0.003$ & 94.3 \\
2.0 & 6.22 & $5.56 \pm 0.10$ & $0.052 \pm 0.000$ & 90.3 \\
3.0 & 9.33 & $7.72 \pm 0.16$ & $0.023 \pm 0.002$ & 83.0 \\
4.0 & 12.44 & $10.8 \pm 0.2$ & $0.026 \pm 0.003$ & 86.9 \\
5.0 & 15.55 & $13.0 \pm 0.6$ & $0.036 \pm 0.004$ & 84.0 \\
\hline
\end{tabular}

Average recovery $(\%)=[\mathrm{Hg}$ recovered from tube 1 and tube $2(\mu \mathrm{g}) \div \mathrm{Hg}$ emission from coal $(\mu \mathrm{g})] \times 100 \%$.

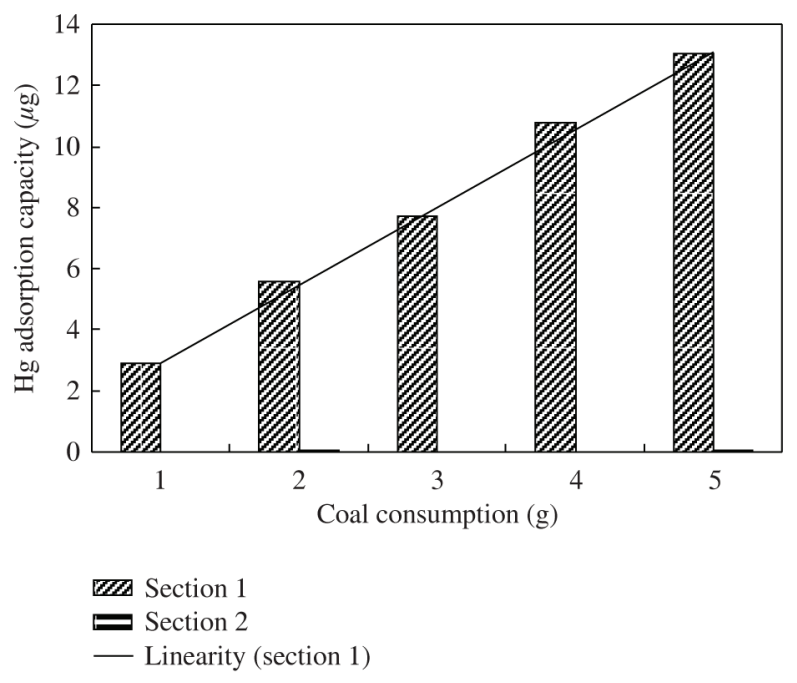

FIGURE 6: Distribution of $\mathrm{Hg}$ in tube 1 and tube 2.

were less than $5 \%$ in different $\mathrm{Hg}$ concentrations in flue gas, which verified that this measurement method of $\mathrm{Hg}$ in flue gas was reliable.

\subsection{The Practice of the Analysis Method in Power Plants}

In order to evaluate the efficiency of this method, the processes of field mercury emission measurements have been practiced in three coal-fired power plants in China. In plant-3, the $\mathrm{OH}$ method has been used simultaneously to get the reference data.

\subsubsection{Coal Analyses}

The coals consumed in three power plants were from different areas and their major components of these coals are listed in Table 6 . The mercury contents in three coals are $0.161,0.064$, and $0.225 \mathrm{mg} / \mathrm{kg}$ respectively, which agree with mercury contents of $0.01-1.0 \mathrm{mg} / \mathrm{kg}$ in Chinese coals [18].

\subsubsection{Distribution of Mercury}

During the process of coal stream in power plant, the mercury in coal is distributed into bottom ash, ESP ash (fly ash), FGD reactant (gypsum), and flue gas. The relative distribution of $\mathrm{Hg}$ and the $\mathrm{Hg}$ concentrations 
TABLE 5: Comparison of $\mathrm{Hg}$ measurements in flue gas between the new sorbent method and $\mathrm{OH}$ method in lab $(n=3)$.

\begin{tabular}{lccccc}
\hline \multirow{2}{*}{$\begin{array}{l}\text { Coal consumption } \\
(\mathrm{g})\end{array}$} & $\begin{array}{l}\text { Hg emission } \\
\text { from coal }(\mu \mathrm{g})\end{array}$ & \multicolumn{2}{c}{ Recovered $\mathrm{Hg}(\mu \mathrm{g})$} & \multicolumn{2}{c}{ Average recovery (\%) } \\
\hline 1.0 & 3.11 & $2.88 \pm 0.07$ & $2.81 \pm 0.11$ & 92.6 & 90.4 \\
3.0 & 9.33 & $8.01 \pm 0.12$ & $8.21 \pm 0.23$ & 85.9 & 88.0 \\
5.0 & 15.55 & $13.2 \pm 0.5$ & $13.8 \pm 0.6$ & 84.8 & 88.7 \\
\hline
\end{tabular}

TABLE 6: Major components of coals in three power plants (dry air basis).

\begin{tabular}{lccccccc}
\hline $\begin{array}{l}\text { Power } \\
\text { plant no. }\end{array}$ & $\begin{array}{c}\text { Volatile } \\
(\%)\end{array}$ & $\begin{array}{c}\text { Ash } \\
(\%)\end{array}$ & $\begin{array}{c}\text { Moisture } \\
(\%)\end{array}$ & $\begin{array}{c}\mathrm{S} \\
(\%)\end{array}$ & $\begin{array}{c}\mathrm{N} \\
(\%)\end{array}$ & $\begin{array}{c}\mathrm{Cl} \\
(\mathrm{mg} / \mathrm{kg})\end{array}$ & $\begin{array}{c}\mathrm{Hg} \\
(\mathrm{mg} / \mathrm{kg})\end{array}$ \\
\hline 1 & 37.3 & 31.6 & 8.50 & 0.57 & 0.79 & 628 & 0.161 \\
2 & 34.9 & 11.6 & 3.43 & 0.54 & 0.86 & 472 & 0.064 \\
3 & 33.0 & 23.4 & 4.40 & 0.92 & 0.99 & 663 & 0.225 \\
\hline
\end{tabular}

in solid/gas samples in three power plants are summarized in Table 7. These values were the average of the data which varied depending on factors such as the coal type and the operation conditions of plants.

\subsubsection{Overall Mass Balance of Mercury}

Mercury mass balances were estimated and the results are shown in Table 8. The operation parameters such as coal/lime feeding rate, bottom ash production rate, fly ash, and gypsum generation rate were provided from operational records by power plants.

The mercury mass balances were $91.6 \%, 77.1 \%$, and $118 \%$ for the three power plants, respectively. Some uncertainties, which mainly come from the inhomogeneity of the components in the coal/ash/gypsum, slight variations of boiler operating conditions, and the errors of sampling and chemical analysis procedures, will affect the accuracy of the mass balance estimation. If the mass balance closures are between $70 \%$ and $130 \%$, the results are acceptable [17]. All of the results of the three power plants were within this acceptable range, which evidence that the measurement process of $\mathrm{Hg}$ in flue gas was practicable. Some other previous investigations are in relatively similar ranges of recovery. Zhang et al. [19] calculated the $\mathrm{Hg}$ mass balances of six power plants, which varied from $100.3 \%$ to $139.5 \%$. Yokoyama et al. [17] estimated that the mass balances of $\mathrm{Hg}$ for combustion of three type coals were between $89 \%$ and $138 \%$. The recovery rates of $82 \%$ and $99 \%$ were referred by Lee et al. [20].

\subsubsection{Reliability Verification of Flue Gas Measurements with OH Method in Plant-3}

In plant-3, the $\mathrm{Hg}$ measurements in flue gas were performed by the new sorbent method and $\mathrm{OH}$ method simultaneously. As shown in Table 9, the Hg concentrations in flue gas measured through two methods were closed at each sampling site. Although the relative errors between two methods in field were a little higher compared to those in lab, the results got through the new sorbent method were considered acceptable and reliable due to the complex ingredients in real flue gas. 
TABLE 7: Relative distribution of $\mathrm{Hg}$ and the mean concentrations of $\mathrm{Hg}$ in solid/gas samples in three power plants $(n=3)$.

\begin{tabular}{lcccc}
\hline Plant no. & & 1 & 2 & 3 \\
\hline \multirow{4}{*}{ Distribution } & Bottom ash $(\%)$ & 0.110 & $1.00 \times 10^{-2}$ & $4.00 \times 10^{-2}$ \\
& ESP $(\%)$ & 4.30 & 2.17 & 8.75 \\
& WFGD $(\%)$ & 58.0 & 2.21 & 87.1 \\
& Stack $(\%)$ & 29.2 & 72.7 & 21.8 \\
\hline \multirow{3}{*}{ Concentration } & Bottom ash $(\mu \mathrm{g} / \mathrm{kg})$ & $6.96 \pm 1.16$ & $0.420 \pm 0.996$ & $3.25 \pm 3.86$ \\
& Fly ash $(\mu \mathrm{g} / \mathrm{kg})$ & $30.6 \pm 5.50$ & $8.50 \pm 1.31$ & $92.2 \pm 28.6$ \\
& Gypsum $(\mu \mathrm{g} / \mathrm{kg})$ & $156 \pm 6.46$ & $6.22 \pm 1.86$ & $1560 \pm 74.3$ \\
& Stack flue gas $\left(\mu \mathrm{g} / \mathrm{m}^{3}\right)$ & $2.27 \pm 0.58$ & $4.29 \pm 0.45$ & $1.56 \pm 0.68$ \\
\hline
\end{tabular}

TABLE 8: Mass balances of Hg between input and output streams in three power plants $(n=3)$.

\begin{tabular}{lccccc}
\hline & Stream & & Plant-1 & Plant-2 & Plant-3 \\
\hline Input & Coal & $\mathrm{g} / \mathrm{hr}$ & 4.48 & 16.9 & 8.24 \\
\hline \multirow{3}{*}{ Output } & Bottom ash & $\mathrm{g} / \mathrm{hr}$ & $5.00 \times 10^{-3}$ & $2.00 \times 10^{-3}$ & $3.00 \times 10^{-3}$ \\
& Fly ash & $\mathrm{g} / \mathrm{hr}$ & 0.193 & 0.366 & 0.721 \\
& Gypsum & $\mathrm{g} / \mathrm{hr}$ & 2.60 & 0.373 & 7.18 \\
& Stack flue gas & $\mathrm{g} / \mathrm{hr}$ & 1.31 & 12.3 & 1.79 \\
\hline Mass & (Input/output) $\times 100$ & $\%$ & 91.6 & 77.1 & 118 \\
\hline
\end{tabular}

TABLE 9: Comparison of $\mathrm{Hg}$ measurements in flue gas between the new sorbent method and $\mathrm{OH}$ method in plant-3 $(n=3)$.

\begin{tabular}{lccc}
\hline $\begin{array}{l}\text { Hg Concentration in flue gas } \\
\left(\mu \mathrm{g} / \mathrm{m}^{3}\right)\end{array}$ & This method & OH method & Relative error \\
\hline Before ESP & $9.14 \pm 3.54$ & $10.3 \pm 1.9$ & $11.3 \%$ \\
After ESP (before WFGD) & $7.01 \pm 2.83$ & $7.95 \pm 2.32$ & $11.8 \%$ \\
After WFGD & $1.56 \pm 0.68$ & $1.38 \pm 0.84$ & $14.3 \%$ \\
\hline
\end{tabular}

\section{CONCLUSIONS}

This study developed the measurement of mercury in flue gas based on aluminum matrix sorbent. A sorbent trap was used to collect vapor phase $\mathrm{Hg}$ from flue gas and the $\mathrm{Hg}$ on trap was measured using CVAAS followed by acid leaching.

$\mathrm{Hg}$ adsorbed by sorbent was recovered completely by leaching process. The average bias of the analytical technique was $2.68 \%$, and the average recovery of spiked $\mathrm{Hg}^{0}$ in tube 3 varied from $89.7 \%$ to $105 \%$ (averaged 97\%). Hg breakthrough in tube 2 was negligible compared to $\mathrm{Hg}$ content in tube 1 . The average recovery of tube 1 and tube 2 was considered acceptable with the variation of $83.0 \%$ to $94.3 \%$ (averaged $87.7 \%$ ).

The mercury in coal is distributed into bottom ash, ESP ash (fly ash), WFGD reactant (gypsum), and flue gas, and the relative distribution varied depending on factors such as the coal type and the operation conditions of plants. 
The $\mathrm{Hg}$ mass balances of three power plants were $91.6 \%, 77.1 \%$, and $118 \%$ for mercury in coal $(0.161 \mathrm{mg} / \mathrm{kg}, 0.064 \mathrm{mg} / \mathrm{kg}$, and $0.225 \mathrm{mg} / \mathrm{kg})$, respectively, and the relative errors of the results between this method and $\mathrm{OH}$ method were less than $5 \%$ and $15 \%$ for measurements practiced in lab and field, respectively, which indicated that this method can be applied to measure $\mathrm{Hg}$ emissions from coal-fired combustion sources.

Further study is needed for $\mathrm{Hg}$ speciation in flue gas and its model prediction.

\section{ACKNOWLEDGMENT}

This study was supported by the High-Tech R\&D Program of China (863) under Grant no. 2007AA06Z340.

\section{REFERENCES}

[1] E. G. Pacyna, J. M. Pacyna, F. Steenhuisen, and S. Wilson, "Global anthropogenic mercury emission inventory for 2000," Atmospheric Environment, vol. 40, no. 22, pp. 4048-4063, 2006.

[2] U.S. Environmental Protection Agency (USEPA), "Method 101A: determination of particulate and gaseous mercury emissions from sewage sludge incinerators," 1982.

[3] U.S. Environmental Protection Agency (USEPA), "Method 29: methodology for the determination of metals emissions in exhaust gases from hazardous waste incineration and similar combustion processes," 1992.

[4] ASTM D6784-02, "Standard test method for elemental, oxidized, particle-bound, and total mercury in flue gas generated from coal-fired stationary sources (Ontario-Hydro Method)," 2002.

[5] A. D. Shendikar, A. Dample, and W. F. Gutknecht, "Report of research triangle institute," Tech. Rep. EPA-600/784-089, 1984.

[6] R. Meij, "The fate of mercury in coal-fired power plants and the influence of wet flue-gas desulphurization," Water, Air, and Soil Pollution, vol. 56, pp. 21-33, 1991.

[7] E. M. Prestbo and N. S. Bloom, "Mercury speciation adsorption (MESA) method for combustion flue gas: methodology, artifacts, intercomparison, and atmospheric implications," Water, Air, and Soil Pollution, vol. 80, no. $1-4$, pp. $145-158,1995$.

[8] I. Olmez and N. K. Aras, "Mercury determination in environmental materials by instrumental neutron activation analysis," Transactions of the American Nuclear Society, vol. 68, pp. 171-173, 1993.

[9] J. A. Cooper, "Recent advances in sampling and analysis of coal-fired power plant emissions for air toxic compounds," Fuel Processing Technology, vol. 39, no. 1-3, pp. 251-258, 1994.

[10] U.S. Environmental Protection Agency (USEPA), "Method 30B: determination of total vapor phase mercury emissions from coal-fired combustion sources using carbon sorbent traps," 2007.

[11] 40 CFR to Part 75, "Appendix K: quality assurance and operating procedures for sorbent trap monitoring systems," 2007.

[12] R. Meij, H. Spoelstra, and F. J. De Waard, "The determination of gaseous inorganic trace compounds in flue gases from coal-fired power plants," in Proceedings of the 8th World Clean Air Congress, Den Haag, the Netherlands, 1989.

[13] Y. Zhuang, J. Laumb, R. Liggett, M. Holmes, and J. Pavlish, "Impacts of acid gases on mercury oxidation across SCR catalyst," Fuel Processing Technology, vol. 88, no. 10, pp. 929-934, 2007.

[14] X. Zhao, H. Wang, W. Xiao, and J. Wang, "Effect of $\mathrm{SO}_{2}$ on catalytic oxidation of NO over $\mathrm{Co}_{3} \mathrm{O}_{4} / \mathrm{Al}_{2} \mathrm{O}_{3}$," Chinese Journal of Catalysis, vol. 21, no. 3, pp. 239-242, 2000 (Chinese).

[15] Z. Mei, Z. Shen, Q. Zhao et al., "Removing and recovering gas-phase elemental mercury by $\mathrm{Cu}_{x} \mathrm{Co}_{3-x} \mathrm{O}_{4}(0.75 \leq$ $x \leq 2.25$ ) in the presence of sulphur compounds," Chemosphere, vol. 70, no. 8, pp. 1399-1404, 2008.

[16] Z. Mei, Z. Shen, Z. Mei et al., "The effect of N-doping and halide-doping on the activity of $\mathrm{CuCoO}_{4}$ for the oxidation of elemental mercury," Applied Catalysis B, vol. 78, no. 1-2, pp. 112-119, 2008.

[17] T. Yokoyama, K. Asakura, H. Matsuda, S. Ito, and N. Noda, "Mercury emissions from a coal-fired power plant in Japan," Science of the Total Environment, vol. 259, no. 1-3, pp. 97-103, 2000. 
[18] W. Huang and Y. Yang, "Mercury in Chinese coal," Coal Geology China, vol. 14, no. 4, pp. 37-40, 2002 (Chinese).

[19] L. Zhang, Y. Zhuo, L. Chen, X. Xu, and C. Chen, "Mercury emissions from six coal-fired power plants in China," Fuel Processing Technology, vol. 89, no. 11, pp. 1033-1040, 2008.

[20] S. J. Lee, Y. C. Seo, H. N. Jang et al., "Speciation and mass distribution of mercury in a bituminous coal-fired power plant," Atmospheric Environment, vol. 40, no. 12, pp. 2215-2224, 2006.

\section{This article should be cited as follows:}

Juan Wang, Wei Xu, Xiaohao Wang, and Wenhua Wang, "Measurement of Mercury in Flue Gas Based on an Aluminum Matrix Sorbent," TheScientificWorldJOURNAL, vol. 11, pp. 2469-2479, 2011. 


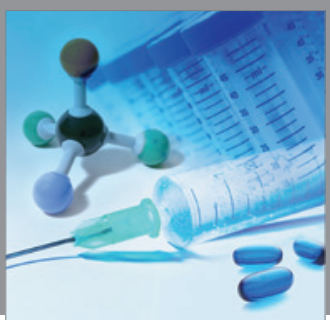

International Journal of

Medicinal Chemistry

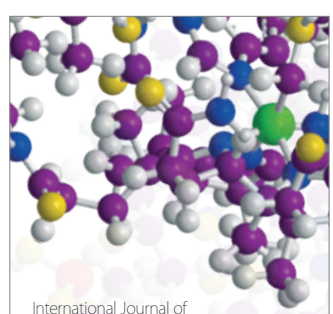

Carbohydrate Chemistry

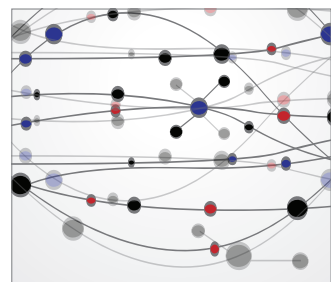

The Scientific World Journal
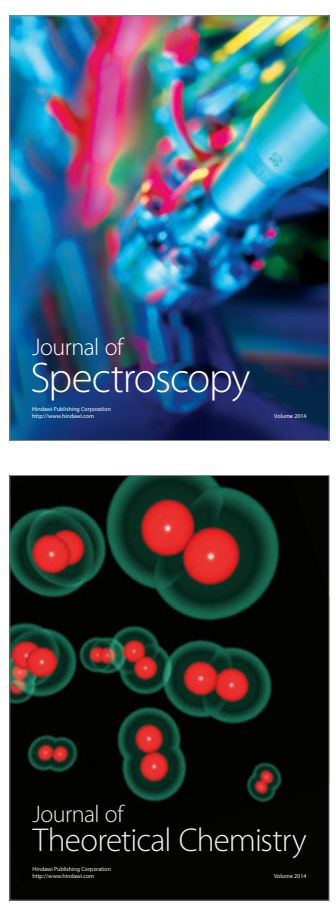
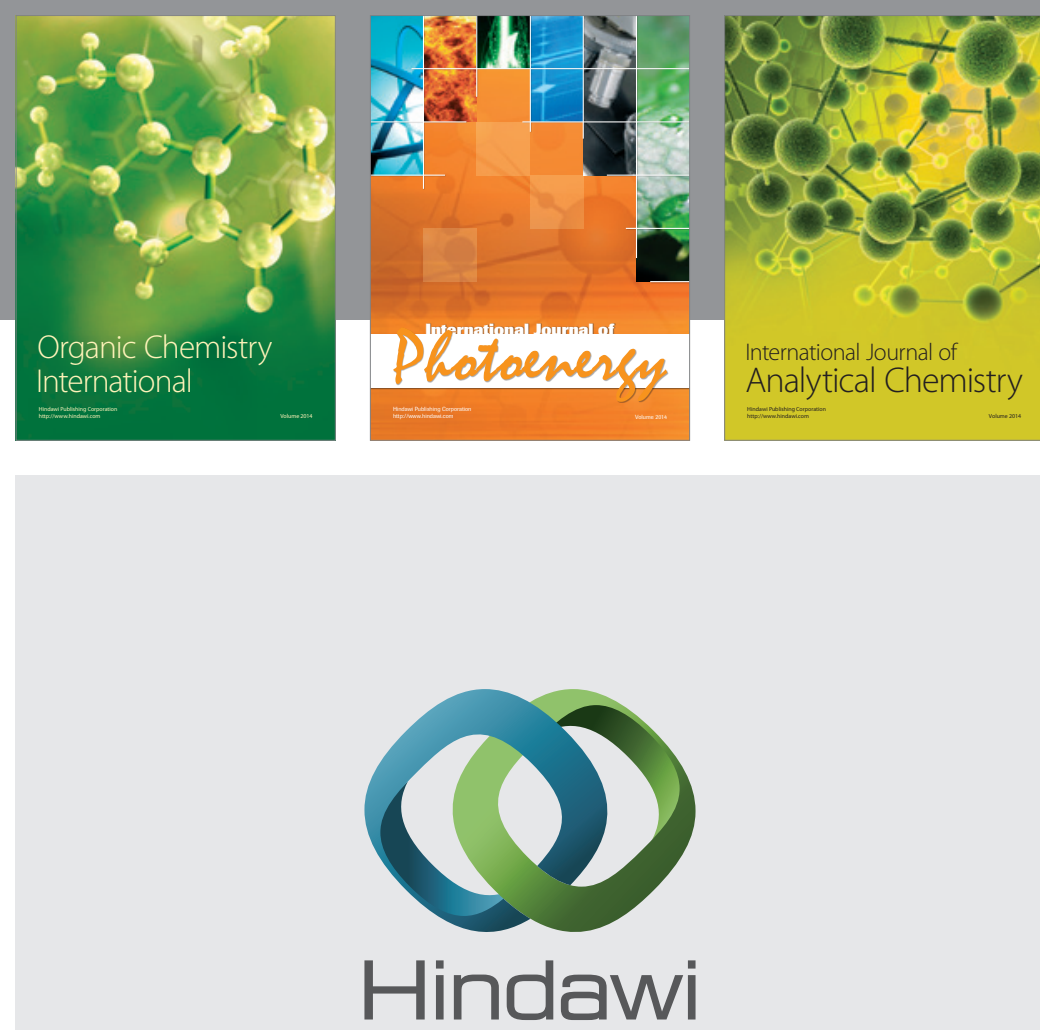

Submit your manuscripts at

http://www.hindawi.com
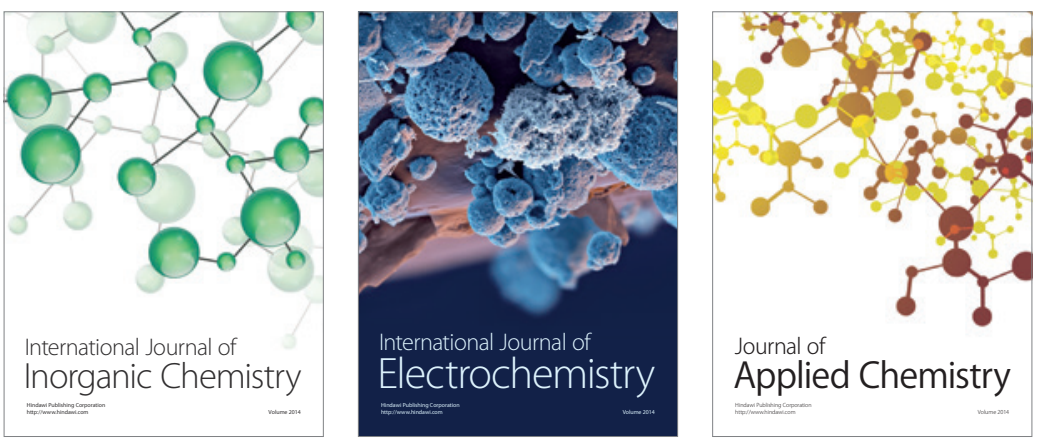

Journal of

Applied Chemistry
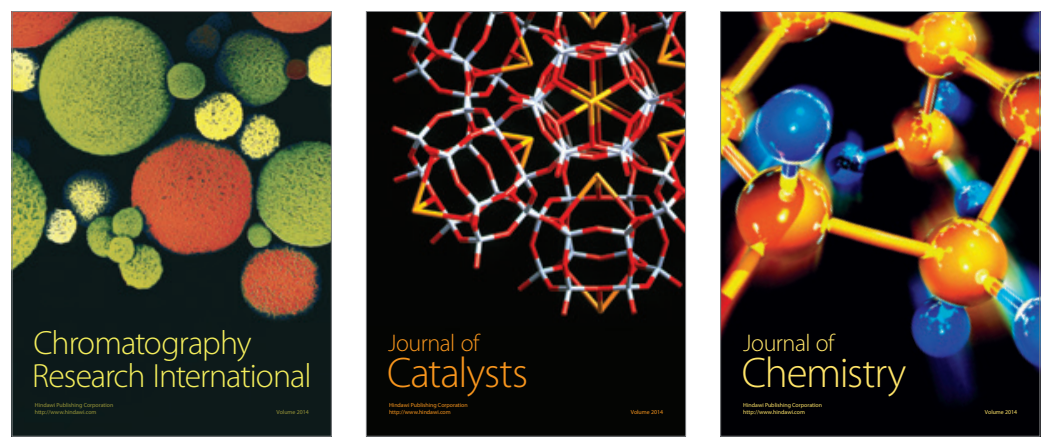
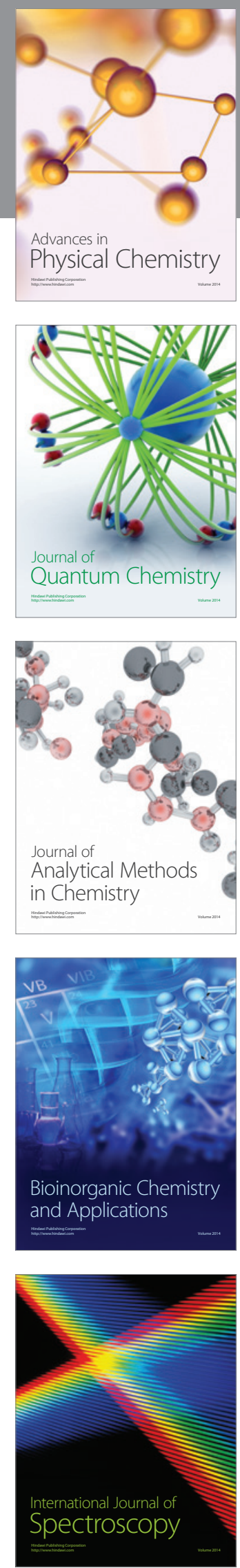